\title{
Spray Coating of Adsorbent with Polymer Latex on Sand Particles for Fluoride Removal in Drinking Water
}

\author{
Hai-Xia Wu, ${ }^{\dagger}$ Ting-Jie Wang, ${ }^{* \dagger}{ }^{\dagger}$ Xiao-Min Dou, ${ }^{\dagger}$ Bei Zhao,${ }^{\S}$ Lin Chen, ${ }^{\dagger}$ and Yong Jin ${ }^{\dagger}$ \\ Department of Chemical Engineering, Tsinghua University, Beijing 100084, China, Research Center for \\ Eco-Environmental Sciences, Chinese Academy of Sciences, Beijing 100085, China, and School of \\ Environmental Science and Engineering, Beijing Forestry University, Beijing 100083, China
}

\begin{abstract}
An iron-aluminum-cerium trimetal hydroxide $(\mathrm{Fe}-\mathrm{Al}-\mathrm{Ce})$ adsorbent with an acrylic-styrene copolymer latex binder, which can cross-link and cure at room temperature, was coated on sand particles by spray coating. The adhesion of the coated layer increased with the latex $/ \mathrm{Fe}-\mathrm{Al}-\mathrm{Ce}$ ratio. A suitable latex $/ \mathrm{Fe}-\mathrm{Al}-\mathrm{Ce}$ ratio and thickness of coated adsorbent were determined to be 0.8 and $70 \mu \mathrm{m}$, respectively, giving good stability and adsorption capacity. The corresponding adsorption capacity of fluoride ions on the coated sand reached $3.46 \mathrm{mg} / \mathrm{g}$ at $\mathrm{pH} 7.0$ and an initial fluoride concentration of $50 \mathrm{mg} / \mathrm{L}$. Sand coated with $\mathrm{Fe}-\mathrm{Al}-\mathrm{Ce}$ is a potential adsorbent for use in a packed bed for fluoride removal from drinking water.
\end{abstract}

\section{Introduction}

A high concentration of fluoride in drinking water causes such maladies as dental and skeletal fluorosis ${ }^{1}$ and is harmful to human health. The guideline values for fluoride in drinking water are set at $1.5 \mathrm{mg} / \mathrm{L}$ by the World Health Organization and 1.0 $\mathrm{mg} / \mathrm{L}$ by China. ${ }^{2}$ Adsorption is considered one of the most efficient technologies for fluoride removal from drinking water when compared with other technologies such as reverse osmosis, ${ }^{3}$ nanofiltration, electrodialysis, ${ }^{4}$ and Donnan dialysis. ${ }^{5}$

Many natural and low-cost materials such as kaolinite, bentonite, charfines, lignite, and nirmali seeds have been used as adsorbents for fluoride removal from water. The adsorption capacities decrease in the order bentonite $>$ charfines $>$ kaolinite $>$ lignite $>$ nirmali seeds, and the highest removal efficiency is around $40 \%$ (for an initial fluoride concentration of $5 \mathrm{mg} / \mathrm{L}$ ) because of their low adsorption capacities. ${ }^{6}$ Rare earth metal hydroxides/oxides are potential adsorbents because of their strong affinities for fluoride. ${ }^{7,8}$ However, rare earth metals are usually expensive, which restricts their use in the treatment of drinking water. Because of the high electronegativity and small ionic size of the fluoride ion, it has a strong affinity toward multivalent metal ions including $\mathrm{Al}(\mathrm{III}), \mathrm{Fe}(\mathrm{III})$, and $\mathrm{Zr}(\mathrm{IV}){ }^{9}$ Thus, a hybrid of a rare earth metal with a cheaper metal such as $\mathrm{Al}(\mathrm{III}), \mathrm{Fe}(\mathrm{III})$, or $\mathrm{Zr}$ (IV) would be an economical way to reduce the use of expensive rare earth metals while maintaining a high fluoride adsorption capacity.

A newly synthesized iron-aluminum-cerium trimetal hydroxide $(\mathrm{Fe}-\mathrm{Al}-\mathrm{Ce})$ adsorbent was reported to have a high adsorption capacity of about $178 \mathrm{mg} / \mathrm{g}$ for an equilibrium fluoride concentration of $84.5 \mathrm{mg} / \mathrm{L}$, with an adsorbent dose of $150 \mathrm{mg} / \mathrm{L}$ and at $\mathrm{pH}$ 7.0. Moreover, the desorption efficiency of fluoride from the used $\mathrm{Fe}-\mathrm{Al}-\mathrm{Ce}$ adsorbent reached $97 \%$ with $\mathrm{NaOH}$ solution at $\mathrm{pH} 12.2 .^{2}$ However, the $\mathrm{Fe}-\mathrm{Al}-\mathrm{Ce}$ adsorbent powder was only nanoscale in size, which made solid/

* To whom correspondence should be addressed. Tel.: +86-1062788993. Fax: +86-10-62772051. E-mail: wangtj@mail.tsinghua.edu.cn.

${ }^{\dagger}$ Tsinghua University.

* Beijing Forestry University.

${ }^{\S}$ Chinese Academy of Sciences. liquid separation difficult, and the $\mathrm{Fe}-\mathrm{Al}-\mathrm{Ce}$ powder cannot be used in a packed bed.

After being granulated at about $1 \mathrm{~mm}$ pellets, the $\mathrm{Fe}-\mathrm{Al}-\mathrm{Ce}$ adsorbent still showed a promising performance through column experimental examination; specifically, the capability reached 2240 bed volumes of water with an initial fluoride concentration of $5.5 \mathrm{mg} / \mathrm{L}$ that fell below $1.0 \mathrm{mg} / \mathrm{L}$ after treatment. ${ }^{2}$ The adsorption of fluoride mainly occurs in the outer region of the adsorbent pellets because of diffusion resistance, leading to a low utilization efficiency of the adsorbent and a high cost of water treatment.

Lai et al. and Lo and Chen reported that iron oxide coated on a large particle carrier is a promising way to remove toxic ions from drinking water, ${ }^{10,11}$ because this approach enabled the adsorbent to be used in a packed bed and reduced the cost of the adsorbent. However, the reported amounts of the coating layer were below $1 \%,{ }^{12-14}$ which resulted in low adsorption capacities. The maximum capacity for fluoride removal using manganese-oxide-coated alumina (MOCA) was only $2.85 \mathrm{mg}$ / $\mathrm{L}$, which included $1.08 \mathrm{mg} / \mathrm{L}$ adsorption contributed by the alumina core particles. ${ }^{15}$ Furthermore, the coated layers were easily shed, which left the carrier with little adsorption capacity and caused secondary pollution in the drinking water.

This study was aimed at developing a granulation approach by coating $\mathrm{Fe}-\mathrm{Al}-\mathrm{Ce}$ adsorbent on the sand particle surface with an acrylic-styrene copolymer latex as a binder to reinforce the adhesion strength and stability of the coating layer for fluoride removal in drinking water.

\section{Experimental Section}

2.1. Materials. $\mathrm{FeSO}_{4} \cdot 7 \mathrm{H}_{2} \mathrm{O}, \quad \mathrm{Al}_{2}\left(\mathrm{SO}_{4}\right)_{3} \cdot 12 \mathrm{H}_{2} \mathrm{O}$, and $\mathrm{Ce}\left(\mathrm{SO}_{4}\right)_{2} \cdot 4 \mathrm{H}_{2} \mathrm{O}$, all analytical grade, were obtained from Chemical Engineering Company of Beijing, (Beijing, China). The other chemicals used were analytical reagent (AR) grade.

Acrylic-styrene copolymer latex, which can cross-link and cure at room temperature, was supplied by the Institute of Polymer Science \& Technology (Department of Chemical Engineering, Tsinghua University, Beijing, China). This had a solid fraction of $40 \%$ and a dynamic viscosity of $20 \mathrm{cP}$ at 20 

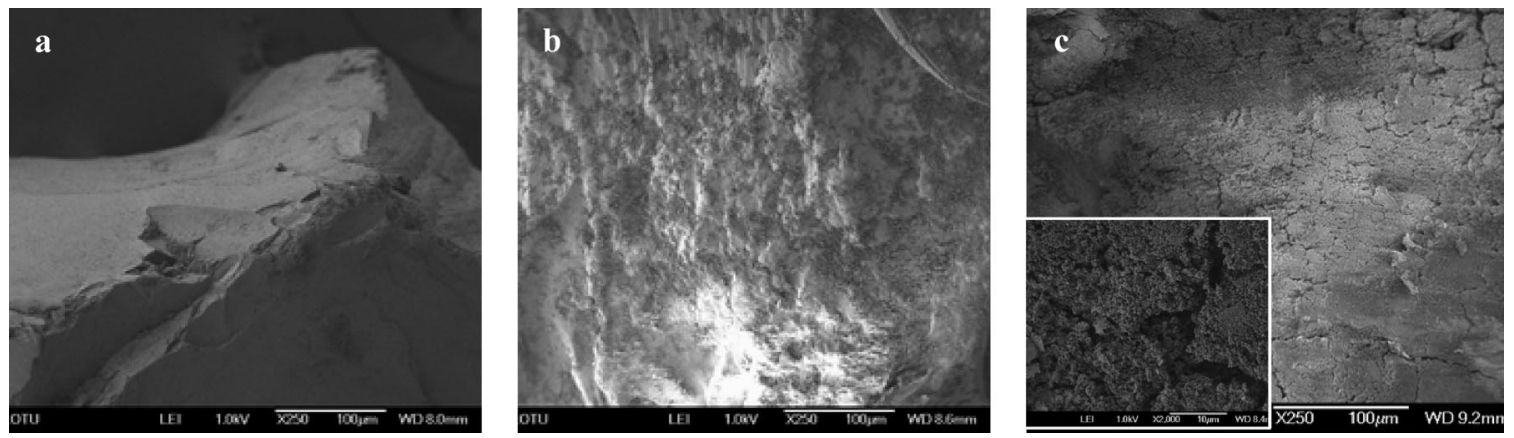

Figure 1. Surface morphology of the sample during the coating process: (a) precoated sand, (b) coated sand (after 10 min), (c) coated sand (after 60 min).

${ }^{\circ} \mathrm{C}$. The glass transformation temperature of the polymer latex was $22.8^{\circ} \mathrm{C}$.

The sand (Gaoyuan Stone Company, Beijing, China) was sieved to give the $0.5-1.0 \mathrm{~mm}$ fraction, soaked in $\mathrm{HCl}$ solution $(\mathrm{pH} 1.0)$ for $4 \mathrm{~h}$, rinsed with deionized water until the $\mathrm{pH}$ reached $6.0 \pm 0.2$, and dried at $105{ }^{\circ} \mathrm{C}$ for $24 \mathrm{~h}$. The sand obtained was kept in capped bottles.

2.2. Preparation of $\mathbf{F e}-\mathbf{A l}-\mathbf{C e}$ Adsorbent. $\mathrm{FeSO}_{4} \cdot 7 \mathrm{H}_{2} \mathrm{O}$, $\mathrm{Al}_{2}\left(\mathrm{SO}_{4}\right)_{3} \cdot 12 \mathrm{H}_{2} \mathrm{O}$, and $\mathrm{Ce}\left(\mathrm{SO}_{4}\right)_{2} \cdot 4 \mathrm{H}_{2} \mathrm{O}$ were dissolved in deionized water to form a mixed solution with concentrations of $0.1,0.2$, and $0.1 \mathrm{M}$, respectively. Six molar $\mathrm{NaOH}$ solution was slowly added into the mixed solution until the $\mathrm{pH}$ reached 9.5. The solution was stirred at $200 \mathrm{rpm}$ during the whole process. $^{2}$ The precipitates obtained were centrifuged and washed with deionized water until the $\mathrm{pH}$ of the filtrate was $6.5 \pm 0.2$. The product, iron-aluminum-cerium trimetal hydroxide $(\mathrm{Fe}-\mathrm{Al}-\mathrm{Ce})$ adsorbent with a diameter of $40 \mathrm{~nm}$, was kept in deionized water.

2.3. Coating. A suspension of $\mathrm{Fe}-\mathrm{Al}-\mathrm{Ce}$ mixed with acrylic-styrene copolymer latex at a set concentration was used as the coating reagent. The coating process was an improved process based on the literature. ${ }^{12,16,17}$ Sand (20 g) was placed uniformly on a glass tray to give a $0.5-\mathrm{cm}$-thick layer. The coating reagent was sprayed onto the sand as a fine mist. Then, the sand was dried with hot air at $42{ }^{\circ} \mathrm{C}$ until the water was evaporated, with stirring of the sand throughout. These steps were repeated until all of the prepared coating reagent had been used. To prevent the formation of liquid bridges and agglomeration of sand particles, the coating reagent was sprayed onto the sand intermittently. After the spray coating was completed, the coated particles were kept in capped bottles.

2.4. Fluoride Adsorption Examination. ${ }^{2}$ A $1000 \mathrm{mg} / \mathrm{L}$ fluoride solution was prepared by dissolving $1.1050 \mathrm{~g}$ of $\mathrm{NaF}$ in $500 \mathrm{~mL}$ of distilled water. Fluoride-containing solutions were prepared by diluting this solution to set concentrations with deionized water. Set volumes of fluoride solution were added separately to conical flasks to which $\mathrm{NaClO}_{4}$ with a concentration of $0.1 \mathrm{M}$ had been added as the background electrolyte. The adsorbent was dosed to give $5 \mathrm{~g} / \mathrm{L}$, and the final volume was increased to $100 \mathrm{~mL}$ with distilled water. The $\mathrm{pH}$ of the test solution was kept at $6.5-7.5$ by addition of $0.05 \mathrm{M} \mathrm{HClO}_{4}$ or $0.05 \mathrm{M} \mathrm{NaOH}$. The test solution was shaken at $180 \mathrm{rpm}$ and $25^{\circ} \mathrm{C}$ for $24 \mathrm{~h}$ during the adsorption test. After that, the solutions were filtered with a $0.45-\mu \mathrm{m}$ membrane filter for analysis. The fluoride ion concentration of the filtrate was analyzed with a fluoride selective electrode connected to an ion meter (IM-40S, TOA Electronics Ltd., Tokyo, Japan).

2.5. Characterization. The morphology and structure of the sand coated with the $\mathrm{Fe}-\mathrm{Al}-\mathrm{Ce}$ adsorbent were examined by high-resolution scanning electron microscopy (HRSEM, JSM
7401, JEOL Co., Tokyo, Japan). The samples were coated with a thin gold layer before HRSEM observation. The specific surface areas of the adsorbent samples were determined with a specific surface area analyzer (Autosorb-1-C, Quantachrome Instruments, Boynton Beach, FL) using nitrogen adsorption.

To qualitatively evaluate the adhesion of the coated layer on the particle surface, the adhesion of the coated layer on a glass plate was measured with reference to the standard of paints and varnishes cross-cut test (ISO 2409-1992). ${ }^{18}$ First, the coating reagent was sprayed onto the glass plate surface, and the plate was dried with hot air at $42{ }^{\circ} \mathrm{C}$, which formed a thin film. Second, the film of $100 \mathrm{~mm}^{2}$ was divided uniformly into 100 panes. Third, an adhesive tape was applied to the plate with the panes was pasted and then removed. The number of panes remaining divided by 100 was used as the measure to evaluate the adhesion of the coated layer. The average of three measurements was taken to be the adhesion of the coating layer.

The ratio of the mass of $\mathrm{Fe}-\mathrm{Al}-\mathrm{Ce}$ shed to the mass of the remaining coated layer was used to characterize the mechanical stability. Coated sand (with weight $W_{1}$ ) was added to $100 \mathrm{~mL}$ of deionized water, and after $24 \mathrm{~h}$ agitation at $250 \mathrm{rpm}$ in a shaker, the sand was filtered and dried at $50{ }^{\circ} \mathrm{C}$ for $48 \mathrm{~h}$ to obtain the remaining weight $\left(W_{2}\right)$. The stability $S$ is defined as

$$
S=\frac{W_{1}-W_{2}}{W_{1}(1+L) R /[1+(1+L) R]} \times 100
$$

where $R$ is the $\mathrm{Fe}-\mathrm{Al}-\mathrm{Ce} /$ sand ratio and $L$ is the latex/ $\mathrm{Fe}-\mathrm{Al}-\mathrm{Ce}$ ratio.

\section{Results and Discussion}

3.1. Analysis of the Coating Process. Experiments showed that sand can be coated by spray coating. Particle samples were taken during the coating process for analysis. Typical SEM images of the samples are shown in Figure 1. Figure 1a shows the surface image of the precoated sand. The sharp edges on the surface are clearly seen. After a few minutes of coating, the edges were covered with discrete patches of $\mathrm{Fe}-\mathrm{Al}-\mathrm{Ce}$ adsorbent, as shown in Figure 1b. With further coating, more $\mathrm{Fe}-\mathrm{Al}-\mathrm{Ce}$ adsorbent was deposited, forming a thick layer, and the sand surface was smoothly covered, as shown in Figure 1c.

However, Figure 1c shows many cracks in the coated layer of the $\mathrm{Fe}-\mathrm{Al}-\mathrm{Ce}$ adsorbent (also see the magnified cracks in the inset image). During adsorbent deposition and film layer formation, the stress present was due to water evaporation, which resulted in the creation of cracks or defects. Because $\mathrm{Fe}-\mathrm{Al}-\mathrm{Ce}$ particles are very rigid, the stress cannot be released through particle deformation, which easily leads to cracks in the coated layers, as shown in Figure 1c. The cracks made the coating layer fragile, so that it had a lower stability and was easily shed. 


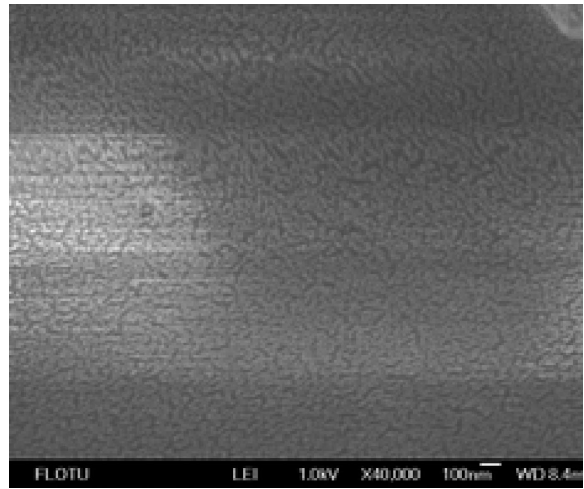

Figure 2. Morphology of cured latex on a glass plate.

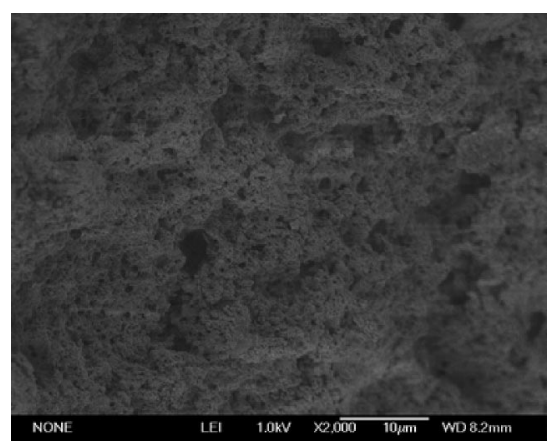

Figure 3. Morphology of the sand coated with $\mathrm{Fe}-\mathrm{Al}-\mathrm{Ce}$ and latex.

Therefore, a binder is needed to increase the stability of the coated layer.

Acrylic-styrene copolymer latex (latex for short) was employed as a binder in the layer coating process because of its promising properties: it is tough, soft, nontoxic, and curable at ambient temperature. Figure 2 shows the morphology of the cured latex film. When the latex was sprayed onto a substrate, it condensed and accumulated due to the evaporation of water. Then, the latex particles deformed, cross-linked, and cured to form a film layer. When the latex was introduced into the coated layer, the cracks were decreased or disappeared, as shown in Figure 3.

As the metal oxide is hard and the latex is soft, when latex is introduced, stress can be released through the deformation of the latex particles, thus allowing cracks to be reduced or eliminated. Moreover, after the latex cross-linked and cured, the bonding strength among the $\mathrm{Fe}-\mathrm{Al}-\mathrm{Ce}$ particles within the coated layer and between the particles and the substrate sand increased. The $\mathrm{Fe}-\mathrm{Al}-\mathrm{Ce}$ adsorbent coating process is mainly through bonding by latex, so calcination, which leads to the loss of $\mathrm{Fe}-\mathrm{Al}-\mathrm{Ce}$ active sites, is not needed in the granulation process.

3.2. Effect of the Latex/Fe-Al-Ce Ratio. The effect of the latex $/ \mathrm{Fe}-\mathrm{Al}-\mathrm{Ce}$ ratio on the structure and adhesion of the coated layer was investigated. Figure 4 shows the SEM images of the sand coated with different latex $/ \mathrm{Fe}-\mathrm{Al}-\mathrm{Ce}$ ratios, with the $\mathrm{Fe}-\mathrm{Al}-\mathrm{Ce} / \mathrm{sand}$ ratio kept at 0.05 . When the latex/ $\mathrm{Fe}-\mathrm{Al}-\mathrm{Ce}$ ratio was lower than 0.2 , it had little effect on the morphology of the coated film, which was similar to that obtained in the absence of latex, and the coated layer had many cracks. When the latex/ $\mathrm{Fe}-\mathrm{Al}-\mathrm{Ce}$ ratio reached 0.8 , the cracks changed to pores, and when the latex $/ \mathrm{Fe}-\mathrm{Al}-\mathrm{Ce}$ ratio reached 3.2 , the pores decreased, and a film formed. Generally speaking, as the latex $/ \mathrm{Fe}-\mathrm{Al}-\mathrm{Ce}$ ratio increased, the morphology of the coated layer changed from having cracks to having pores to forming a film.

The surface area of the precoated sand was $0.04 \mathrm{~m}^{2} / \mathrm{g}$, and the pore volume was $0.0002 \mathrm{~mL} / \mathrm{g}$. For the coated sand with a fixed $\mathrm{Fe}-\mathrm{Al}-\mathrm{Ce} / \mathrm{sand}$ ratio of 0.05 and varying latex/ $\mathrm{Fe}-\mathrm{Al}-\mathrm{Ce}$ ratios, the specific surface areas and total pore volumes of the coated layer can be obtained by subtracting the contribution of sand, as shown in Figure 5. When the latex/ $\mathrm{Fe}-\mathrm{Al}-\mathrm{Ce}$ ratio was changed from 0 to 3.2 , the surface area of the coated layer changed from 30.61 to $0.43 \mathrm{~m}^{2} / \mathrm{g}$, and the pore volume changed from 0.1598 to $0.0094 \mathrm{~mL} / \mathrm{g}$. The specific surface areas of the coated layer and the pore volume changed dramatically by about 2 orders of magnitude.
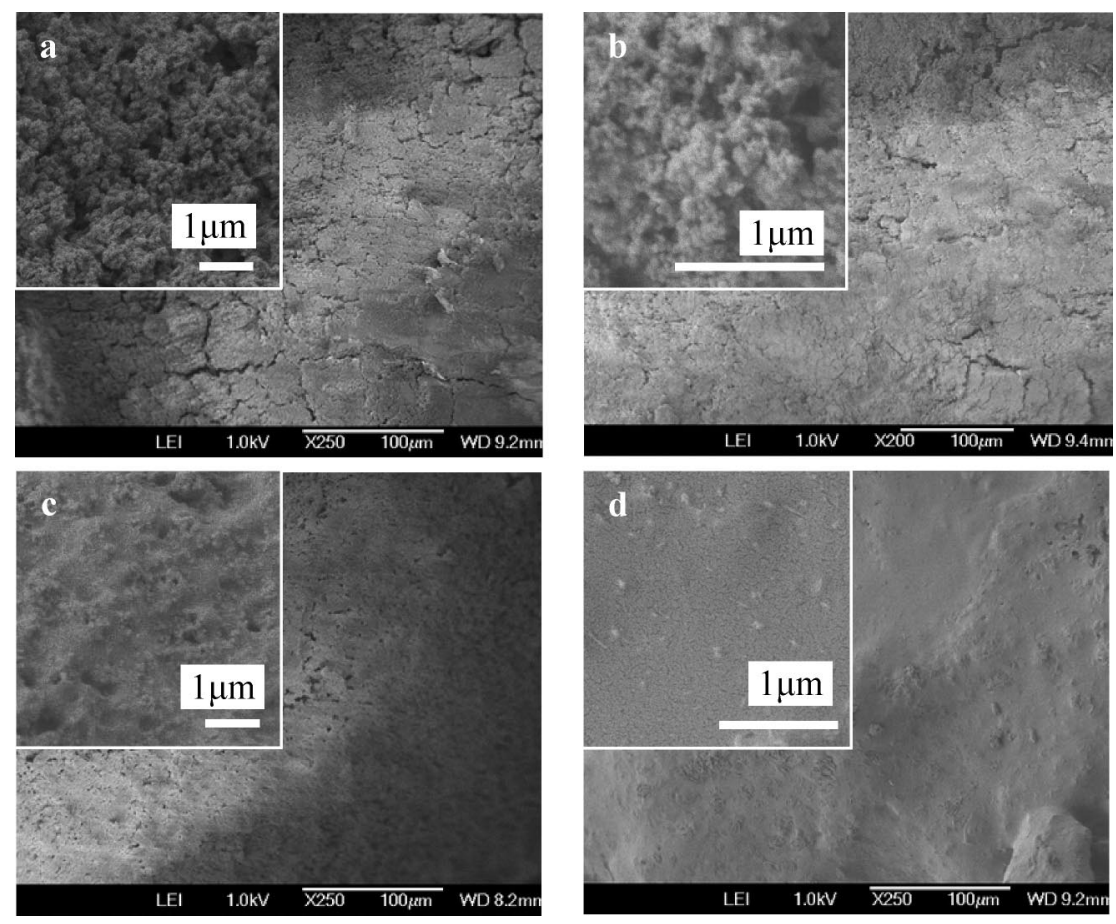

Figure 4. $\mathrm{SEM}$ images of the sand coated at $\mathrm{Fe}-\mathrm{Al}-\mathrm{Ce} / \mathrm{sand}=0.05$ and latex/Fe$-\mathrm{Al}-\mathrm{Ce}=$ (a) 0, (b) 0.2, (c) 0.8, (d) 3.2 . 


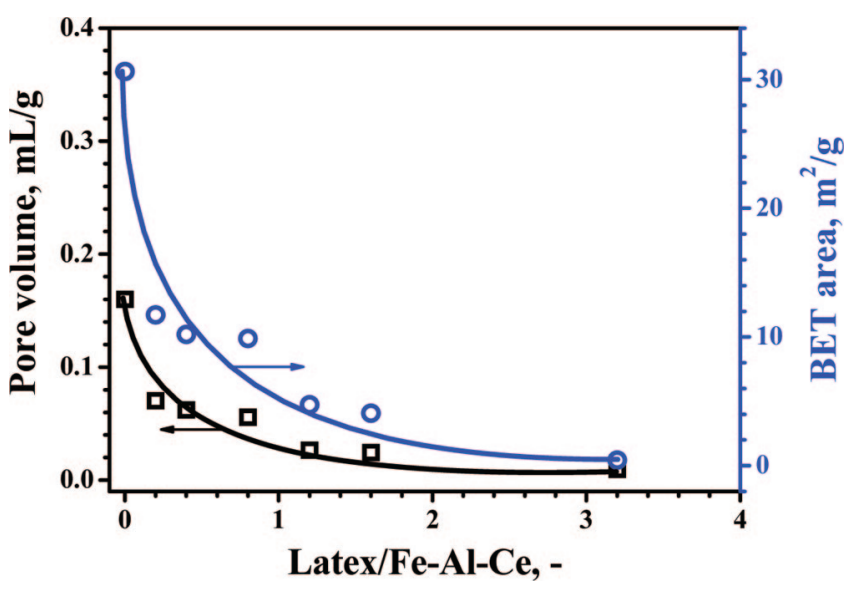

Figure 5. Surface area and pore volume of the coated layer at $\mathrm{Fe}-\mathrm{Al}-\mathrm{Ce} /$ sand $=0.05$.

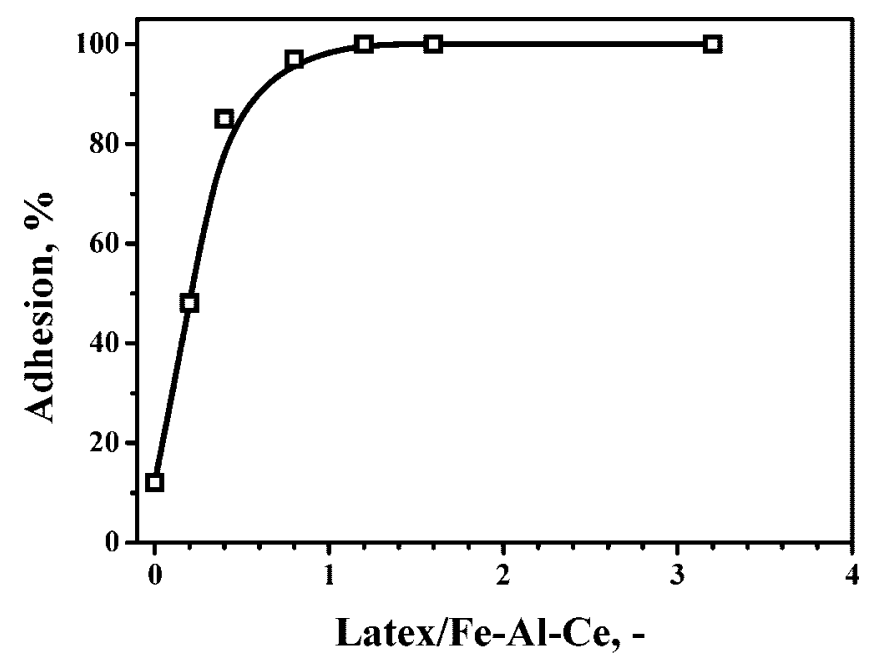

Figure 6. Coating adhesion of the film on the glass plate at $\mathrm{Fe}-\mathrm{Al}-\mathrm{Ce} /$ sand $=0.05$.

When the latex/ $\mathrm{Fe}-\mathrm{Al}-\mathrm{Ce}$ ratio was below 0.2 , the amount of latex was assumed to be insufficient to link the adsorbent particles and efficiently eliminate stress; thus, cracks could not be completely avoided, and the specific surface area and pore volume were large. When the latex $/ \mathrm{Fe}-\mathrm{Al}-\mathrm{Ce}$ ratio reached 3.2, water evaporation and latex particle deformation led to the submerging of the $\mathrm{Fe}-\mathrm{Al}-\mathrm{Ce}$ adsorbent particles in the latex particles. After the latex cross-linked, a layer of film formed, and the $\mathrm{Fe}-\mathrm{Al}-\mathrm{Ce}$ adsorbent particles were sealed in the film, causing a dramatic decrease of the specific surface area and pore volume, almost to 0 . When the latex $/ \mathrm{Fe}-\mathrm{Al}-\mathrm{Ce}$ ratio was 0.8 , the amount of latex was not sufficient for a film to form, but the latex could bridge and cross-link, so the cracks could be eliminated, leaving many pores in the coating layer.

Figure 6 shows the change in the adhesion of films with increasing latex $/ \mathrm{Fe}-\mathrm{Al}-\mathrm{Ce}$ ratios coated on a glass plate. When the latex $/ \mathrm{Fe}-\mathrm{Al}-\mathrm{Ce}$ ratio was increased from 0.2 to 0.4 , the adhesion increased significantly from $48 \%$ to $85 \%$. When the latex $/ \mathrm{Fe}-\mathrm{Al}-\mathrm{Ce}$ ratio reached 1.2 , the adhesion of the coating reached $100 \%$. This large improvement is probably due to the disappearance of cracks in the coated layer and the strong bonding of the coated materials. The latex plays a key role in increasing the adhesion among the $\mathrm{Fe}-\mathrm{Al}-\mathrm{Ce}$ particles and between the particles and the sand surface.

The surface area and pore volume have a large effect on the adsorbent capacity. By taking into consideration the effects of adhesion, the specific surface area, and the pore volume, the latex $/ \mathrm{Fe}-\mathrm{Al}-\mathrm{Ce}$ ratio $(R)$ was set at 0.8 as the optimum value for the subsequent experiments.

3.3. Effect of Coating Thickness. Figure 7 shows the morphology of sand coated with different amounts of $\mathrm{Fe}-\mathrm{Al}-\mathrm{Ce}$ at a latex $/ \mathrm{Fe}-\mathrm{Al}-\mathrm{Ce}$ ratio of 0.8 . With increasing coated amount, the edges and roughness of the sand surface faded, and a smooth surface appeared gradually, as shown in Figure $7 \mathrm{a}-\mathrm{d}$. A section image of the coated sand sample at an $\mathrm{Fe}-\mathrm{Al}-\mathrm{Ce} /$ sand ratio of 0.075 is shown in the inset of Figure $7 \mathrm{c}$. The thickness of the coated layer reached $70 \mu \mathrm{m}$, which is much greater than the previously reported thicknesses of $4-7 \mu \mathrm{m} .{ }^{19}$ It is inferred that the high thickness is mainly attributable to the latex bonding. However, with a further increase in the coated layer thickness, cracks occurred on the surface, as shown in Figure $7 d$. This resulted in a decrease of the stability of the coating.

The stabilities of sand coated with different amounts of $\mathrm{Fe}-\mathrm{Al}-\mathrm{Ce}$ are shown in Figure 8. These data indicate that the stability first increases with increasing coated amount, then reaches a maximum, and decreases with a further increase of the coated thickness.

From Figures 7 and 8, it is inferred that, when the coated amount was low, the coating did not form a continuous layer; instead, the $\mathrm{Fe}-\mathrm{Al}-\mathrm{Ce}$ adsorbent was attached to the sand surface in dispersed clusters, so the stability was not high. With increased coated amount, the clusters of $\mathrm{Fe}-\mathrm{Al}-\mathrm{Ce}$ adsorbent bonded with each other to form a continuous coating layer, which led to an increase in stability. When the coated amount increased further, the thickness of the coated layer increased, and stress accumulated, so that when water remaining in the layer further evaporated, cracks formed, leading to a decrease of the stability. Therefore, the coating thickness cannot be increased without limit.

3.4. Adsorption Capacity of the Coated Adsorbent. The fluoride adsorption capacity was examined for coated sand with different latex $/ \mathrm{Fe}-\mathrm{Al}-\mathrm{Ce}$ ratios. The results are shown in Figure 9. This figure shows that the amount of adsorbed fluoride first increased with the latex/ $\mathrm{Fe}-\mathrm{Al}-\mathrm{Ce}$ ratio and then decreased. It is inferred that, when the latex/ $\mathrm{Fe}-\mathrm{Al}-\mathrm{Ce}$ ratio lower than 0.8 , the low adhesion strength resulted in $\mathrm{Fe}-\mathrm{Al}-\mathrm{Ce}$ adsorbent loss and that, the lower the amount of latex, the higher the amount of adsorbent lost. It has been reported that $\mathrm{Fe}-\mathrm{Al}-\mathrm{Ce}$ adsorbent adsorbs fluoride ions through the exchange of hydroxyl ions on the active adsorption sites. ${ }^{2}$ The introduction of latex also brings about a decrease of the specific surface area and pore volume, resulting in the decrease in the number of active adsorption sites and the adsorption capacity. Figure 9 shows that the adsorption capacity reaches a maximum for a latex $/ \mathrm{Fe}-\mathrm{Al}-\mathrm{Ce}$ ratio of 0.8 .

The fluoride adsorption capacities of coated sand with different coated amounts at initial fluoride concentration of 50 $\mathrm{mg} / \mathrm{L}$ and $\mathrm{pH} 7.0$ are shown in Figure 10. Curve a shows that the fluoride adsorption capacity per unit mass of coated sand increased with increasing coated amount, but the rate of increase gradually decreased. Curve $b$ shows that the fluoride adsorption capacity per unit mass of $\mathrm{Fe}-\mathrm{Al}-\mathrm{Ce}$ adsorbent decreased with increasing coated amount, with the rate of decrease also decreasing gradually. It is inferred that the adsorption efficiency of $\mathrm{Fe}-\mathrm{Al}-\mathrm{Ce}$ decreased with increased coating thickness or coating amount.

Taking into consideration the adsorption capacity and coating stability, a coating thickness of $70 \mu \mathrm{m}$ is suggested for fluoride removal from drinking water. Using this thickness of coated 

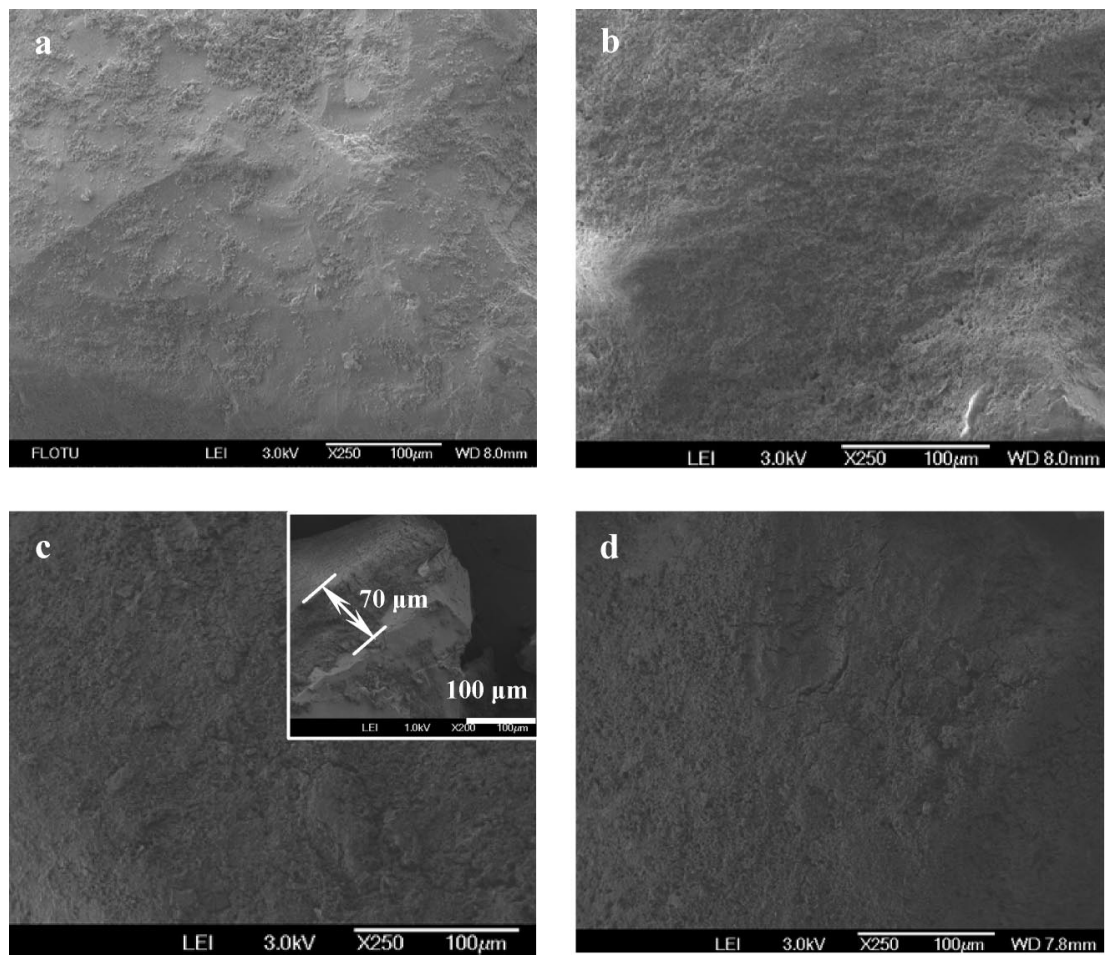

Figure 7. SEM images of the sand coated at latex/ $\mathrm{Fe}-\mathrm{Al}-\mathrm{Ce}=0.8$ (the inset image in Figure $7 \mathrm{c}$ shows the cross section) $\mathrm{Fe}-\mathrm{Al}-\mathrm{Ce} / \mathrm{sand}$ : a, $0.3 \%$; b, $0.6 \% ; \mathrm{c}, 7.5 \%$;, $15 \%$.

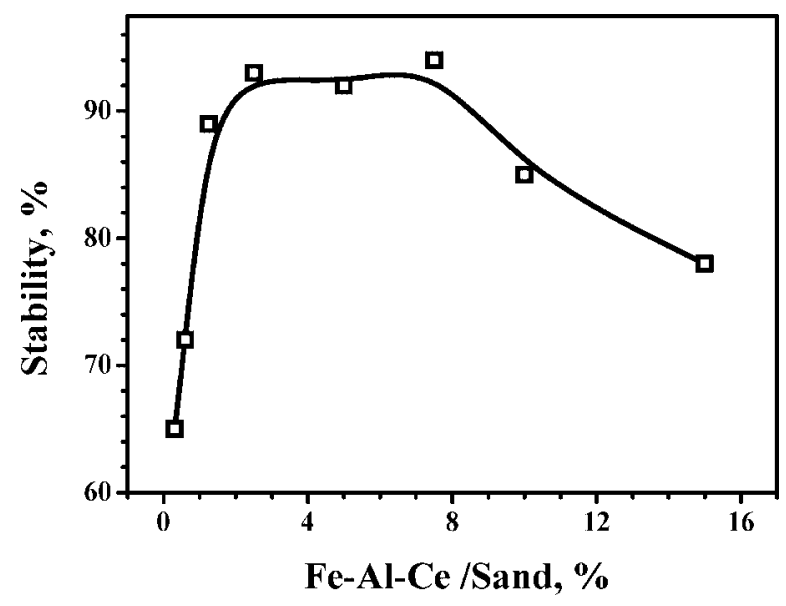

Figure 8. Stability of the coated layer at latex $/ \mathrm{Fe}-\mathrm{Al}-\mathrm{Ce}=0.8$.

adsorbent, the fluoride adsorption capacity is about $3.46 \mathrm{mg} / \mathrm{g}$ (coated sand) at $\mathrm{pH} 7.0$ and an initial fluoride concentration of $50 \mathrm{mg} / \mathrm{L}$.

Sand is a promising selection as a carrier because of its high strength and low cost, which is less than $1 \%$ of the cost of the $\mathrm{Fe}-\mathrm{Al}-\mathrm{Ce}$ adsorbent. The granulated adsorbent obtained by spray coating $\mathrm{Fe}-\mathrm{Al}-\mathrm{Ce}$ adsorbent on the sand particle surface can be operated in a packed bed for drinking water treatment. The utilization efficiency of $\mathrm{Fe}-\mathrm{Al}-\mathrm{Ce}$ powder adsorbents can be markedly increased compared with that obtained by granulation with pure adsorbents.

\section{Conclusion}

$\mathrm{An} \mathrm{Fe}-\mathrm{Al}-\mathrm{Ce}$ adsorbent with a polymer latex as a binder was developed and coated on sand by spraying. The introduction of the acrylic-styrene copolymer latex released stress in the coated layer. With increasing latex $/ \mathrm{Fe}-\mathrm{Al}-\mathrm{Ce}$ ratio, the adhesion of the coated layer increased, and the surface morphology

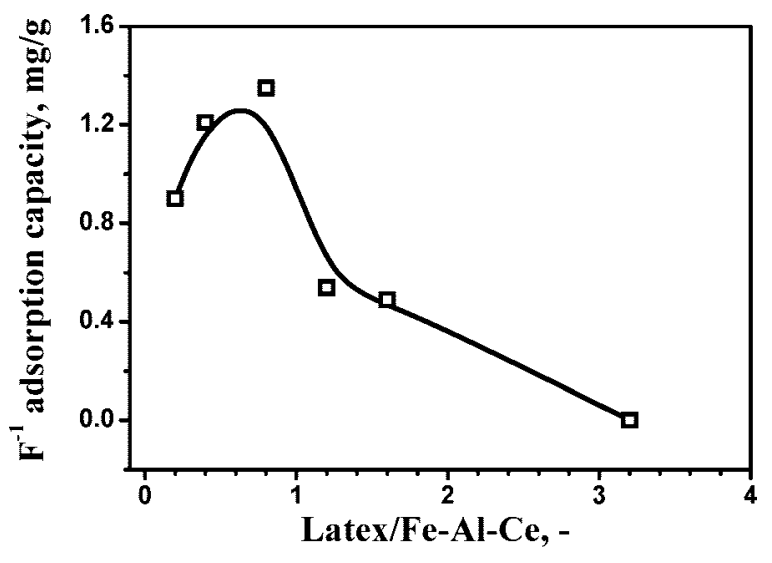

Figure 9. Fluoride adsorption capacity at $\mathrm{Fe}-\mathrm{Al}-\mathrm{Ce} / \mathrm{sand}=0.05$.

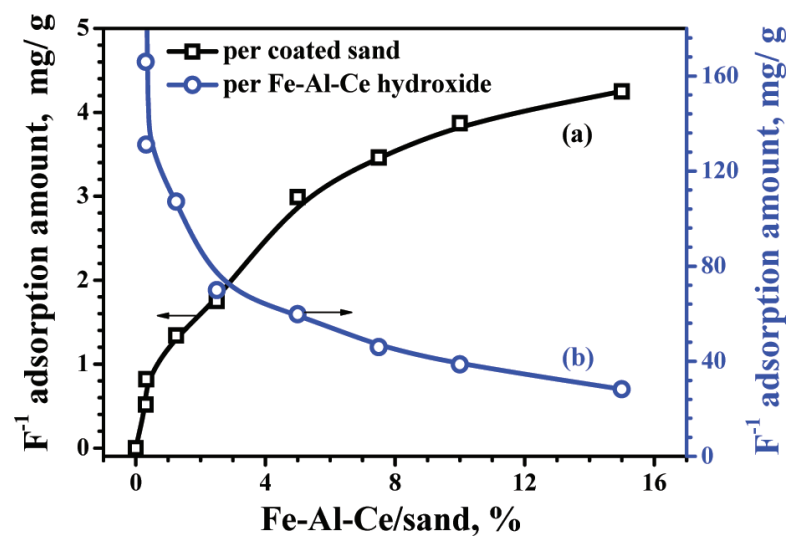

Figure 10. Fluoride adsorption capacity at latex $/ \mathrm{Fe}-\mathrm{Al}-\mathrm{Ce}=0.8, \mathrm{pH} 7.0$, and an initial fluoride concentration of $50 \mathrm{mg} / \mathrm{L}$.

of the coated sand changed from having cracks to having pores to being a film. 
For an acceptable adsorption capacity and stability of the coated layer, a latex $/ \mathrm{Fe}-\mathrm{Al}-\mathrm{Ce}$ ratio of 0.8 and a thickness of $70 \mu \mathrm{m}$ for the coated layer of $\mathrm{Fe}-\mathrm{Al}-\mathrm{Ce}$ are suggested. Using coated sand with these properties, the fluoride adsorption capacity was $3.46 \mathrm{mg} / \mathrm{g}$ at $\mathrm{pH} 7.0$ and an initial fluoride concentration of $50 \mathrm{mg} / \mathrm{L}$.

\section{Acknowledgment}

The authors express their appreciation for the financial support of this study by the National High Technology Research and Development Program of China (863 Program, No. 2007AA06Z319) and the Specialized Research Fund for the Doctoral Program of Higher Education (No. 20060003089).

\section{Literature Cited}

(1) Abe, I.; Iwasaki, S.; Tokimoto, T.; et al. Adsorption of fluoride ions onto carbonaceous materials. J. Colloid Interface Sci. 2004, 275, 35.

(2) Wu, X. M.; Zhang, Y.; Dou, X. M.; et al. Fluoride removal performance of a novel $\mathrm{Fe}-\mathrm{Al}-\mathrm{Ce}$ trimetal oxide adsorbent. Chemosphere 2007, 69, 1758.

(3) Maurice, S. O.; Hitoki, M. Chapter 1 Fluoride Removal from Water Using Adsorption Technique. Adv. Fluorine Sci. 2006, $2,1$.

(4) Sahli, M. A. M.; Annouar, S.; Tahaikt, M.; et al. Fluoride removal for underground brackish water by adsorption on the natural chitosan and by electrodialysis. Desalination 2007, 212, 37.

(5) Hocine, G.; Francoise, P.; Jacqueline, S.; et al. Defluoridation of groundwater by a hybrid process combining adsorption and Donnan dialysis. Desalination 2002, 145, 287.

(6) Srimurali, M.; Pragathi, A.; Karthikeyan, J. A study on removal of fluorides from drinking water by adsorption onto low-cost materials. Environ. Pollut. 1998, 99, 285.

(7) Raichur, A. M.; Basu, M. J. Adsorption of fluoride onto mixed rare earth oxides. Sep. Purif. Technol. 2001, 24, 121.
(8) Zhou, Y. M.; Yu, C. X.; Shan, Y. Adsorption of fluoride from aqueous solution on $\mathrm{La}^{3+}$-impregnated cross-linked gelatin. Sep. Purif. Technol. 2004, 36, 89 .

(9) Luo, F.; Inoue, K. The removal of fluoride ion by using metal(III)loaded Amberlite resins. Solv. Extr. Ion Exch. 2004, 22, 305.

(10) Lai, C. H.; Chen, C. Y.; Wei, B. L.; et al. Cadmium adsorption on goethite-coated sand in the presence of humic acid. Water Res. 2002, 36, 4943.

(11) Lo, S. L.; Chen, T. Y. Adsorption of Se(IV) and Se(VI) on an iron-coated sand from water. Chemosphere 1997, 35, 919.

(12) Lukasik, J.; Cheng, Y. F.; Lu, F. H.; et al. Removal of microorganisms from water by columns containing sand coated with ferric and aluminum hydroxides. Water Res. 1999, 33, 769.

(13) Bolster, C. H.; Mills, A. L.; Hornberger, G. M.; et al. Effect of surface coatings, grain size, and ionic strength on the maximum attainable coverage of bacteria on sand surfaces. J. Contam. Hydrol. 2001, 50, 287.

(14) Al-Sewailem, M. S.; Khaled, E. M.; Mashhady, A. S. Retention of copper by desert sands coated with ferric hydroxides. Geoderma 1999, 89, 249.

(15) Maliyekkal, S. M.; Sharma, A. K.; Philip, L. Manganese-oxidecoated alumina: A promising sorbent for defluoridation of water. Water Res. 2006, 40, 3497.

(16) Neiss, J.; Stewart, B. D.; Nico, P. S.; et al. Speciation-dependent microbial reduction of uranium within iron-coated sands. Environ. Sci. Technol. 2007, 41, 7343.

(17) Guo, H. M.; Stuben, D.; Berner, Z. Arsenic removal from water using natural iron mineral-quartz sand columns. Sci. Total Environ. 2007, $377,142$.

(18) Zmihorska-Gotfryd, A. Coating compositions based on modified phenol-formaldehyde resin and urethane prepolymers. Prog. Org. Coat. 2004, 49, 109.

(19) Lai, C. H.; Lo, S. L.; Chiang, H. L. Adsorption/desorption properties of copper ions on the surface of iron-coated sand using BET and EDAX analyses. Chemosphere 2000, 41, 1249.

Received for review February 18, 2008 Revised manuscript received April 30, 2008 Accepted May 4, 2008

IE800278B 